ISSN 1678-3921

Journal homepage: www.embrapa.br/pab

For manuscript submission and journal contents, access: www.scielo.br/pab

\section{Supplementation of grazing beef cattle with narasin}

\begin{abstract}
The objective of this work was to evaluate the effect of narasin inclusion in mineral and protein supplements on the performance and supplement intake of grazing beef yearlings. One hundred and fifty Nellore yearlings with $17.0 \pm 0.06$ months of age and $219.7 \pm 1.62 \mathrm{~kg}$ initial body weight (BW) were allocated into 30 experimental units (EUs), with five animals each. The EUs were assigned to 16 paddocks, which were continuously stocked for 28 days, followed by 28 days of rest. A randomized complete block design was used. The experiment lasted 140 days, divided into five periods of 28 days each. The assessed treatments were: control mineral supplement $(\mathrm{CON})$; $\mathrm{CON}+1,800(\mathrm{~N} 1800)$ or 2,750 (N2750) mg narasin per kilogram of supplement; and protein mineral supplement (PROT) or PROT + $360 \mathrm{mg}$ narasin per kilogram of supplement (PROT 360). The inclusion of narasin in the mineral supplement increased average daily gain (ADG) in the first period and decreased supplement intake in the first, second, and third periods, when compared with the CON treatment. The ADG and supplement intake were similar between the N1800 and N2750 treatments. Narasin has a positive effect on ADG up to 28 days of supplementation and controls mineral supplement intake, without compromising this gain.
\end{abstract}

Index terms: Bos indicus, ionophore, nutrition.

\section{Suplementação de gado de corte em pastejo com narasina}

Resumo - O objetivo deste trabalho foi avaliar a inclusão de narasina em suplementos mineral e proteico sobre o desempenho e o consumo de suplemento de novilhos de corte em pastagem. Cento e cinquenta novilhos

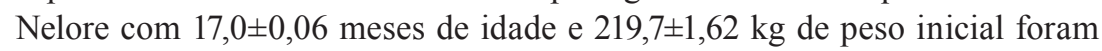
distribuídos em 30 unidades experimentais (UEs), com cinco animais cada uma. As UEs foram dispostas em 60 piquetes, os quais foram pastejados continuamente por 28 dias, seguidos de 28 dias de descanso. Utilizou-se o delineamento de blocos ao acaso. O tempo de duração do experimento foi de 140 dias, dividido em cinco períodos experimentais de 28 dias cada um. Os tratamentos avaliados foram: suplemento mineral controle (CON); CON + 1.800 (N1800) ou 2.750 (N2750) mg de narasina por quilograma de suplemento; e suplemento mineral proteinado (PROT) ou PROT $+360 \mathrm{mg}$ de narasina por quilograma de suplemento (PROT 360). A inclusão de narasina na mistura mineral aumentou o ganho médio diário (GMD) durante o primeiro período e reduziu o consumo de suplemento no primeiro, no segundo e no terceiro períodos, quando comparado ao tratamento CON. O GMD e o consumo de suplemento foram semelhantes entre os tratamentos N1800 e N2750. A narasina tem efeito positivo no GMD até 28 de suplementação e controla o consumo de suplemento mineral, sem comprometer esse ganho.

Termos para indexação: Bos indicus, ionóforos, nutrição. 


\section{Introduction}

The use of ionophores in mineral mixtures is an economical and easy alternative for producers who are trying to improve cattle performance (Sartori et al., 2017). In the literature, divergent results have been reported regarding the effect of these additives on the performance of cattle under grazing systems, as reviewed by Bretschneider et al. (2008), which may be explained by the daily variations in mineral supplement intake (Bagley et al., 1988; Sartori et al., 2017). Although ionophores have been shown to improve the performance of beef cattle on pasture (Sartori et al., 2017; Polizel et al., 2018), their use is limited, likely due to the labor required for their administration in grazing conditions.

Narasin is an ionophore used as a coccidiostat in poultry (Jeffers et al., 1988) and as a growth promoter in swine (Arkfeld et al., 2015). Because of its ability to carry ions through cell membranes, this molecule can be used as a growth promoter in ruminant nutrition, selecting rumen bacteria and protozoa (Azzaz et al., 2015). However, there are few promising studies assessing narasin as a growth promoter in ruminant diets, especially in the field, which could lead to beneficial responses in rumen parameters (Polizel et al., 2020) and animal performance (Polizel et al., 2020) when combined with high forage contents. According to Polizel et al. (2018), the addition of narasin did not cause any reductions in mineral supplement intake, which is an indicative that the inclusion of narasin in mineral and protein supplements may improve yearling performance, without affecting supplement intake.

The objective this work was to evaluate the effect of narasin inclusion in mineral and protein supplements on the performance and supplement intake of grazing beef yearlings.

\section{Materials and Methods}

The experiment was carried out from March to August 2016, at the Hildegard Georgina Von Pritzelwitz experimental station, located in the municipality of Londrina, in the state of Paraná, Brazil (2334'41"S, $\left.50^{\circ} 57^{\prime} 08^{\prime \prime} \mathrm{W}\right)$. Londrina has a subtropical humid climate, Cfa according to Köppen's classification, with precipitation in all seasons (Alvares et al., 2013), although droughts may occur during the winter period from March to July, when the study was conducted.
The protocols for this experiment were approved by the ethics committee on animal use of Faculdade de Medicina Veterinária e Zootecnia of Universidade de São Paulo (number 4431141016).

A hundred and fifty Nellore yearlings with $17.0 \pm 0.06$ months of age and $219.7 \pm 1.62 \mathrm{~kg}$ initial body weight (BW) were allocated according to initial BW into 30 experimental units (EUs), consisting of a group of five animals each. At the beginning of the experiment, all EUs were allocated in the same grazing pressure, so the animal mass was similar among them. The EUs were assigned to six modules with ten paddocks each, totaling 60 paddocks of 1.0 ha, planted with the Urochloa brizantha (A.Rich.) R.D.Webster Marandu cultivar and containing waterers and feeders (mineral boxes). The paddocks were continuously stocked for 28 days, followed by 28 days of rest. Each group of ten paddocks was considered as a block effect. The experiment lasted 140 days, divided into five periods of 28 days each; variables were determined at the end of each period.

The EUs were randomly assigned to one of the five following treatments: mineral control $(\mathrm{CON})$; $\mathrm{CON}+$ $1,800 \mathrm{mg}$ narasin per kilogram of supplement as a fed basis (N1800); CON + 2,750 mg narasin per kilogram of supplement (N2750); protein mineral supplement with $22 \%$ crude protein (PROT); and PROT $+360 \mathrm{mg}$ narasin per kilogram of supplement (PROT 360). The mineral and chemical composition of the treatments is presented in Table 1. The BellNutri 90 supplement (Trouw Nutrition, Mirassol, SP, Brazil) was used for the CON, N1800, and N2750 treatments, whereas Lambisk SA (Trouw Nutrition, Campinas, SP, Brazil) was used for PROT and PROT 360.

The offered supplements and orts were weighed every two days on the 1.0-g accuracy Toledo 9094C/4 electronic scale (Toledo do Brasil, São Bernardo do Campo, SP, Brazil). Both supplements and orts were sampled to determine dry matter (DM), according to method 934.01 of Association of Official Analytical Chemists (Horwitz, 2000), and to calculate the supplement intake in each EU. The mineral supplement was offered ad libitum, allowing orts of at least $10 \%$ of the offered amount. Due to an above-expected intake, the daily supply of protein supplements was adjusted from the third experimental period onwards. The animal's BW and average daily gain (ADG) were assessed every 28 days, after 16 hours of solid 
and liquid fast, using the idBeck 3.0 electronic scale (Irmãos Beckhauser e Cia Ltda, Paranavaí, PR, Brazil).

Forage samples were collected $15 \mathrm{~cm}$ from the ground on the first, fourteenth, and twenty-eighth day of each experimental period to evaluate the amount of forage in each paddock; on the first and twentyeighth days, the samples were quantitative, and, on the fourteenth day, used to evaluate forage quality (simulated grazing). The quantitative samples were harvested close to the ground using $0.25-\mathrm{m}^{2}$ metallic frames $(0.5 \times 0.5 \mathrm{~m})$ placed on the representative sites. The DM of each sample was obtained after 24 hours in a forced-air oven at $105^{\circ} \mathrm{C}$, following protocol 934.01 (Horwitz, 2000). The sample collected on the fourteenth day of each period was dried in a forced-air oven at $60^{\circ} \mathrm{C}$ and then ground in a $1.0-\mathrm{mm}$ Wiley Mill screen (Marconi Equipamentos para Laboratório Ltda, Piracicaba, SP, Brazil). The final DM content was determined after the samples were oven-dried at $105^{\circ} \mathrm{C}$ for 24 hours, according to protocol 934.01 (Horwitz, 2000). Total nitrogen concentration was determined using the TruMac N Total Nitrogen Analyzer (Leco Corporation, St. Joseph, MI, USA), following protocol 968.06 (Horwitz, 2000), whereas crude protein was obtained by multiplying the total $\mathrm{N}$ content by 6.25 . Mineral matter was determined by heating the samples in a muffle furnace at $550^{\circ} \mathrm{C}$ for 4 hours, as described in protocol 942.05 (Horwitz, 2000). Neutral detergent fiber (NDF) was obtained with heat-stable alphaamylase and sodium sulfite, while acid detergent fiber (ADF) was determined according to Van Soest et al. (1991), using the Ankom 2000 Automated Fiber Analyzer (Ankom Technology, Macedon, NY, USA).

The experimental design was a randomized complete block, in which each group of ten paddocks was considered as a block effect to minimize pasture variation. Each EU consisted of five Nellore yearlings, grouped according to $\mathrm{BW}$ and age. The statistical analyses were performed using the Mixed procedure of the SAS, version 9.0, software (SAS Institute Inc., Cary, NC, USA). All data were subjected to the Shapiro-Wilk and Levene tests to verify the normality and homogeneity of variances, respectively, and discrepant data (outliers - studentized residual $>3$ or $<-3$ ) were removed.

For the data corresponding to supplement intake, ADG and forage quality and availability were analyzed as repeated measures over time. For this, the following statistical model was used: $\mathrm{y}_{\mathrm{ijk}}=\mu+\mathrm{T}_{\mathrm{i}}+\mathrm{b}_{\mathrm{j}}+\mathrm{e}_{\mathrm{ij}}+\mathrm{P}_{\mathrm{k}}$ $+\mathrm{T}_{\mathrm{i}} \mathrm{P}_{\mathrm{k}}+\mathrm{b}_{\mathrm{j}} \mathrm{P}_{\mathrm{k}}+\mathrm{e}_{\mathrm{ijk}}$, where $\mu$ is the overall mean, $\mathrm{T}_{\mathrm{i}}$ is the fixed effect of the treatment, $b_{j}$ is the random block effect, $\mathrm{e}_{\mathrm{ij}}$ is random error $\mathrm{A}, \mathrm{P}_{\mathrm{k}}$ is the fixed effect

Table 1. Warranty levels of the experimental supplements ${ }^{(1)}$.

\begin{tabular}{|c|c|c|c|c|c|}
\hline Ingredients $\left(\mathrm{g} \mathrm{kg}^{-1} \mathrm{DM}\right)$ & $\mathrm{CON}$ & N1800 & $\mathrm{N} 2750$ & PROT & PROT 360 \\
\hline Calcium & 135 & 135 & 135 & 50 & 50 \\
\hline Phosphorus & 90 & 90 & 90 & 12 & 12 \\
\hline Sodium & 125 & 125 & 125 & 20 & 20 \\
\hline Magnesium & 10 & 10 & 10 & 2 & 2 \\
\hline Sulfur & 40 & 40 & 40 & 12 & 12 \\
\hline Zinc & 6.2 & 6.2 & 6.2 & 0.85 & 0.85 \\
\hline Copper & 1.67 & 1.67 & 1.67 & 0.23 & 0.23 \\
\hline Fluorine & 1.5 & 1.5 & 1.5 & 0.2 & 0.2 \\
\hline Manganese & 1.29 & 1.29 & 1.29 & 0.2 & 0.2 \\
\hline Cobalt & 0.1 & 0.1 & 0.1 & 0.014 & 0.014 \\
\hline Iodine & 0.124 & 0.124 & 0.124 & 0.016 & 0.016 \\
\hline Selenium & 0.032 & 0.032 & 0.032 & 0.004 & 0.004 \\
\hline Crude protein & 0 & 0 & 0 & 220 & 220 \\
\hline $\operatorname{Narasin}^{(2)}$ (mg per kg of dry matter) & 0 & 1800 & 2750 & 0 & 360 \\
\hline
\end{tabular}

${ }^{(1)} \mathrm{CON}$, mineral supplement; N1800 and N2750, mineral supplement $+1,800$ or 2,750 mg narasin per kilogram of supplement (BellNutri 90, Trouw Nutrition, Mirassol, SP, Brazil); PROT and PROT 360, protein mineral supplement and PROT + $360 \mathrm{mg}$ of narasin per kilogram of supplement, respectively (Lambisk SA, Trouw Nutrition, Campinas, SP, Brazil). ${ }^{(2)}$ Zimprova 100 (Elanco Saúde Animal, São Paulo, SP, Brazil), containing 10\% of narasin. 
of the period, $\mathrm{T}_{\mathrm{i}} \mathrm{P}_{\mathrm{k}}$ is the fixed effect of the treatment and period interaction, $b_{j} P_{k}$ is the random effect of the block and period interaction, and $\mathrm{e}_{\mathrm{ijk}}$ is random error $\mathrm{B}$.

The BW of yearlings was analyzed using the model: $y_{i j}=\mu+T_{i}+b_{j}+e_{i j}$, where $\mu$ is the overall mean, $T_{i}$ is the fixed effect of the treatment, $b_{j}$ is the random block effect, and $\mathrm{e}_{\mathrm{ij}}$ is the random error.

All data analyzed as repeated measures were put into covariance matrices and tested for compound symmetry, heterogeneous compound symmetry, banded structure, variance components, toeplitz, heterogeneous toeplitz, and autoregressive and autoregressive heterogeneity, being defined according to the lowest value obtained for the corrected Akaike's information criterion (AICC). The effects of the period and treatment $x$ period interaction were defined by the F-test of the analysis of variance. Treatment effects were analyzed by four orthogonal contrasts, which were: CON vs N1800 and N2750; N1800 vs N2750; CON, N1800, and N2750 vs PROT and PROT 360; and PROT vs PROT 360. Treatment means were obtained by the LSMEANS command and considered significant at $5 \%$ probability.

\section{Results and Discussion}

There was no effect of treatment and of the interaction between treatment and period on the quality and quantity of available forage during the experiment (Tables 2 and 3), which made it possible to evaluate treatments and periods separately. Moreover, the experimental design allowed providing similar conditions of forage to the animals, without damaging or privileging any treatment with different forage conditions. However, there was a period effect on all measured characteristics, showing that pasture conditions are dynamic, being influenced by weather (Nepomuceno et al., 2017).

Narasin intake during the experimental period was $0.42,0.65$, and $0.62 \mathrm{mg}$ narasin per kilogram of

Table 2. Forage quantity and quality according to treatments.

\begin{tabular}{|c|c|c|c|c|c|c|c|c|c|c|c|c|}
\hline \multirow[t]{2}{*}{ Item } & \multicolumn{5}{|c|}{ Treatment $^{(1)}$} & \multirow[t]{2}{*}{$\mathrm{SEM}^{(2)}$} & \multicolumn{6}{|c|}{ p-value ${ }^{(3)}$} \\
\hline & $\mathrm{CON}$ & N1800 & N2750 & PROT & PROT 360 & & I & II & III & IV & Period $^{(4)}$ & Treat $\times \operatorname{Per}^{(5)}$ \\
\hline \multicolumn{13}{|l|}{ Forage availability (DM) } \\
\hline Entry (ton) & 13.28 & 13.16 & 12.40 & 12.59 & 12.46 & 0.71 & 0.53 & 0.42 & 0.48 & 0.89 & $<0.01$ & 0.20 \\
\hline Exit (ton) & 12.02 & 11.82 & 11.51 & 10.88 & 11.16 & 0.52 & 0.56 & 0.65 & 0.09 & 0.69 & $<0.01$ & 0.07 \\
\hline \multicolumn{13}{|l|}{ Chemical analysis $(\%)$} \\
\hline Dry matter & 26.13 & 25.81 & 28.42 & 26.29 & 26.19 & 0.98 & 0.34 & 0.03 & 0.50 & 0.93 & $<0.01$ & 0.40 \\
\hline Crude protein & 10.55 & 10.13 & 9.77 & 10.74 & 10.52 & 0.54 & 0.34 & 0.62 & 0.30 & 0.76 & $<0.01$ & 0.50 \\
\hline Neutral detergent fiber & 67.36 & 67.54 & 67.56 & 67.59 & 67.08 & 0.62 & 0.80 & 0.98 & 0.79 & 0.56 & $<0.01$ & 0.43 \\
\hline Acid detergent fiber & 32.65 & 32.69 & 33.24 & 33.12 & 32.58 & 0.50 & 0.62 & 0.45 & 0.98 & 0.45 & $<0.01$ & 0.19 \\
\hline Mineral matter & 11.71 & 11.40 & 11.56 & 11.23 & 11.23 & 0.28 & 0.39 & 0.59 & 0.10 & 0.99 & $<0.01$ & 0.64 \\
\hline
\end{tabular}

${ }^{(1)} \mathrm{CON}$, mineral control; $\mathrm{N} 1800, \mathrm{CON}+1,800 \mathrm{mg}$ of narasin per kilogram of supplement; $\mathrm{N} 2750, \mathrm{CON}+2,750 \mathrm{mg}$ narasin per kilogram of supplement; PROT, protein mineral supplement (22\% crude protein); and PROT 360, PROT $+360 \mathrm{mg}$ of narasin per kilogram of supplement. ${ }^{(2)}$ SEM, standard error of the mean. ${ }^{(3)}$ Orthogonal contrasts: I, CON vs N1800 and N2750; II, N1800 vs N2750; III, CON, N1800, and N2750 vs PROT and PROT 360; and IV, PROT vs PROT 360. ${ }^{(4)}$ Five periods of 28 days. ${ }^{(5)}$ Treatment and period interaction.

Table 3. Forage quality according to the five experimental periods of 28 days.

\begin{tabular}{|c|c|c|c|c|c|c|}
\hline \multirow[t]{2}{*}{ Item } & \multicolumn{5}{|c|}{ Period } & \multirow[t]{2}{*}{$\mathrm{SEM}^{(1)}$} \\
\hline & 1 & 2 & 3 & 4 & 5 & \\
\hline Crude protein & 8.90 & 8.40 & 13.80 & 11.60 & 9.50 & 0.54 \\
\hline Ash & 9.90 & 10.80 & 11.90 & 12.30 & 9.50 & 0.28 \\
\hline Neutral detergent fiber & 69.40 & 68.80 & 65.90 & 65.50 & 67.60 & 0.80 \\
\hline Acid detergent fiber & 32.51 & 32.53 & 31.73 & 32.22 & 36.04 & 0.50 \\
\hline Ether extract & 1.37 & 1.39 & 1.05 & 1.34 & 1.25 & 0.12 \\
\hline Non-fibrous carbohydrates & 10.43 & 10.61 & 7.35 & 9.26 & 9.25 & 0.29 \\
\hline
\end{tabular}

(1)Standard error of the mean. 
BW for treatments N1800, N2750, and PROT 360, respectively. As expected, the intake by yearlings of the protein supplements was greater than that of the mineral supplements (Table 4), which may be attributed to the fact that protein supplements contain concentrates that are more palatable to the ruminants. This high palatability is due to a greater digestibly than that of forage. Furthermore, the protein supplement allowed an additional uptake of nutrients by the Nellore yearlings. The daily metabolic requirements of these yearlings, compared with that of those that only received the mineral supplement, explain why the protein supplement caused a greater BW at the end of experiment. Likewise, Brandão et al. (2016) found that the intake of NDF by steers receiving a protein-energy supplement was greater than that of those fed the mineral supplement. According to these authors, this happened because the steers that received the mineral supplement had only forage as a food source and, when they grazed, they did not consume only leaves. Diets with lower percentages of NDF provide a greater DM intake, which normally increases BW gain.

There was an interaction between treatments and period on supplement intake, which was greater in yearlings fed the $\mathrm{CON}$ treatment than in those receiving N1800 and N2750 in the first, second, and third periods. This result is an indicative that narasin may reduce supplement intake, although no effect was observed in periods 4 and 5 . Therefore, the present study was not able to determine whether narasin reduced or not supplement intake. It is important to highlight that this variable normally shows high variability.

Mineral intake was greater than the expected, varying from 40 to $50 \mathrm{~g}$ per day, in the first, second, and third periods, possibly due to a previously insufficient mineralization. Likewise, the amount of the protein supplement was greater than the expected in the first and second periods, when the inclusion of narasin decreased its intake. When the mineral supplement intake approached the expected amount, in the fourth and fifth periods, similar values were obtained for CON, N1800, and N2750. However, regarding the assessed levels of narasin, there was no effect on mineral supplement intake, as also reported by other authors (Polizel et al., 2017, 2018).

At the beginning of the experiment, protein supply was offered increasingly, so yearlings consuming the entire supply would receive a greater amount of supplement in the next offer. Although the manufacturer recommends 140 to $200 \mathrm{~g}$ protein supplement for each $100 \mathrm{~kg}$ of $\mathrm{BW}$, in the second period, the provided amount was above the projected. Therefore, from the third period onwards, the daily supply of protein supplement was fixed at $500 \mathrm{~g}$ per animal as a fed basis. The difference between the observed and expected intake may be explained by the fact that the offered product normally includes the ionophore monensin, which is known to reduce the intake of supplements (Fieser et al., 2007).

Table 4. Supplement intake (gram per day; means \pm standard error of the mean) according to the treatments in each of the five experimental periods of 28 days.

\begin{tabular}{|c|c|c|c|c|c|c|c|c|c|c|c|}
\hline \multirow[t]{2}{*}{ Period } & \multicolumn{5}{|c|}{ Treatment $^{(1)}$} & \multicolumn{6}{|c|}{ p-value ${ }^{(2)}$} \\
\hline & $\mathrm{CON}$ & N1800 & $\mathrm{N} 2750$ & PROT & PROT 360 & I & II & III & IV & Period $^{(3)}$ & Treat $\times \operatorname{Per}^{(4)}$ \\
\hline & $86.1 \pm 6.94$ & $60.0 \pm 4.89$ & $61.1 \pm 3.89$ & $469.8 \pm 10.44$ & $448.5 \pm 8.13$ & $<0.01$ & 0.89 & $<0.01$ & 0.01 & $<0.01$ & $<0.01$ \\
\hline Period 1 & $118.8 \pm 7.62$ & $86.6 \pm 8.72$ & $89.4 \pm 5.82$ & $418.4 \pm 1.72$ & $395.8 \pm 9.38$ & $<0.01$ & 0.76 & $<0.01$ & 0.03 & - & - \\
\hline Period 2 & $128.5 \pm 12.14$ & $76.6 \pm 12.88$ & $70.5 \pm 6.26$ & $577.9 \pm 2.31$ & $511.1 \pm 19.20$ & $<0.01$ & 0.71 & $<0.01$ & $<0.01$ & - & - \\
\hline Period 3 & $76.1 \pm 9.47$ & $51.3 \pm 8.78$ & $46.2 \pm 4.76$ & $439.6 \pm 5.45$ & $438.3 \pm 4.92$ & $<0.01$ & 0.58 & $<0.01$ & 0.90 & - & - \\
\hline Period 4 & $55.1 \pm 6.62$ & $41.8 \pm 2.74$ & $50.9 \pm 6.98$ & $459.9 \pm 2.66$ & $444.9 \pm 8.38$ & 0.26 & 0.31 & $<0.01$ & 0.08 & - & - \\
\hline Period 5 & $52.1 \pm 6.62$ & $43.8 \pm 6.13$ & $48.7 \pm 4.37$ & $453.1 \pm 2.89$ & $452.2 \pm 2.99$ & 0.25 & 0.41 & $<0.01$ & 0.86 & - & - \\
\hline
\end{tabular}

${ }^{(1)} \mathrm{CON}$, mineral control; $\mathrm{N} 1800, \mathrm{CON}+1,800 \mathrm{mg}$ of narasin per kilogram of supplement; $\mathrm{N} 2750, \mathrm{CON}+2,750 \mathrm{mg}$ narasin per kilogram of supplement; PROT, protein mineral supplement (22\% crude protein); and PROT 360, PROT $+360 \mathrm{mg}$ of narasin per kilogram of supplement. ${ }^{(2)}$ Orthogonal contrasts: I, CON vs N1800 and N2750; II, N1800 vs N2750; III, CON, N1800, and N2750 vs PROT and PROT 360; and IV, PROT vs PROT 360. ${ }^{(3)}$ Period effect. ${ }^{(4)}$ Treatment and period interaction. 
Treatment $\mathrm{x}$ period interactions were observed for ADG, with higher values in the N1800 and N2750 treatments than in $\mathrm{CON}$ in the first experimental period (Tabel 5); however, there was no effect in the subsequent periods. There was also no effect of the different levels of narasin on ADG in any of the evaluated periods. In addition, yearlings receiving mineral supplement with 1,800 or $2,750 \mathrm{mg} \mathrm{kg}^{-1}$ narasin had a greater $(\mathrm{p}=0.01) \mathrm{BW}$ than those fed the control at the end of the first period (Table 6); however, there was no effect of narasin on the BW of yearlings in the other periods and BW did not differ between narasin levels. Since pasture production and composition was similar over time and no treatment and period interaction was observed, no pasture characteristic justified the effect of narasin only in the first period.
These results show that narasin improves ADG during the initial period of mineral supplementation and suggest that the microorganisms developed resistance to the ionophores, as reported in studies on monensin (Russel \& Strobel, 1989).

However, few studies have evaluated the effect of narasin on the metabolism of grazing ruminants, especially during long periods of consumption. Polizel et al. (2020) assessed the ruminal parameters and nutrient digestibility of steers fed diets with a high inclusion of forage supplemented with narasin for five months, and found that there was no interaction between treatment and experimental period, showing that the exposure time to narasin did not affect the studied variables. In the present study, the lack of improvement in animal performance may also be

Table 5. Average daily gain (means \pm standard error of the mean) according to the treatments of the five experimental periods of 28 days.

\begin{tabular}{|c|c|c|c|c|c|c|c|c|c|c|c|}
\hline \multirow[t]{2}{*}{ Periods } & \multicolumn{5}{|c|}{ Treatments $^{(1)}$} & \multicolumn{6}{|c|}{ P-value ${ }^{(2)}$} \\
\hline & $\mathrm{CON}$ & N1800 & N2750 & PROT & PROT 360 & I & II & III & IV & Period & Treat $\times$ Per \\
\hline & $510.2 \pm 28.64$ & $519.1 \pm 27.72$ & $532.2 \pm 27.73$ & $573.4 \pm 36.91$ & $606.0 \pm 35.34$ & 0.65 & 0.74 & $<0.01$ & 0.41 & $<0.01$ & 0.01 \\
\hline Period 1 & $498.7 \pm 79.22$ & $698.2 \pm 70.23$ & $703.3 \pm 66.15$ & $799.0 \pm 47.52$ & $827.4 \pm 31.70$ & 0.01 & 0.96 & $<0.01$ & 0.75 & - & - \\
\hline Period 2 & $748.5 \pm 63.72$ & $611.5 \pm 97.98$ & $617.1 \pm 55.90$ & $887.0 \pm 30.05$ & $830.3 \pm 35.11$ & 0.07 & 0.94 & $<0.01$ & 0.48 & - & - \\
\hline Period 3 & $586.2 \pm 62.03$ & $518.4 \pm 75.81$ & $545.5 \pm 82.06$ & $591.4 \pm 48.71$ & $651.2 \pm 43.80$ & 0.48 & 0.77 & 0.23 & 0.51 & - & - \\
\hline Period 4 & $430.2 \pm 50.94$ & $414.1 \pm 30.75$ & $427.3 \pm 77.50$ & $379.4 \pm 69.43$ & $453.0 \pm 35.51$ & 0.89 & 0.87 & 0.89 & 0.36 & - & - \\
\hline Period 5 & $287.1 \pm 37.60$ & $352.3 \pm 65.82$ & $369.4 \pm 52.78$ & $209.9 \pm 71.51$ & $269.4 \pm 81.53$ & 0.61 & 0.88 & 0.10 & 0.56 & - & - \\
\hline
\end{tabular}

(1) CON, mineral control; N1800, CON +1,800 mg of narasin per kilogram of supplement; $\mathrm{N} 2750, \mathrm{CON}+2,750 \mathrm{mg}$ narasin per kilogram of supplement; PROT, protein mineral supplement (22\% crude protein); PROT 360, PROT $+360 \mathrm{mg}$ of narasin per kilogram of supplement. ${ }^{(2)}$ Orthogonal contrasts: I, CON vs N1800 and N2750; II, N1800 vs N2750; III, CON, N1800, and N2750 vs PROT and PROT 360; and IV, PROT vs PROT 360. ${ }^{(3)}$ Period effect. ${ }^{(4)}$ Treatment and period interaction.

Table 6. Body weight (BW; means \pm standard error of the mean) per treatment in each of the five experimental periods of 28 days.

\begin{tabular}{|c|c|c|c|c|c|c|c|c|c|}
\hline \multirow{2}{*}{ Period } & \multicolumn{5}{|c|}{ Treatment $^{(1)}$} & \multicolumn{4}{|c|}{ p-value $e^{(2)}$} \\
\hline & $\mathrm{CON}$ & N1800 & $\mathrm{N} 2750$ & PROT & PROT 360 & I & II & III & IV \\
\hline Initial BW & $219.6 \pm 0.08$ & $219.7 \pm 0.13$ & $219.7 \pm 0.24$ & $219.6 \pm 0.20$ & $219.6 \pm 0.19$ & 0.88 & 1.00 & 0.89 & 1.00 \\
\hline \multicolumn{10}{|l|}{ Final BW } \\
\hline Period 1 & $233.6 \pm 1.82$ & $239.2 \pm 1.92$ & $239.3 \pm 1.69$ & $242.0 \pm 1.65$ & $242.8 \pm 0.79$ & 0.01 & 0.96 & $<0.01$ & 0.75 \\
\hline Period 2 & $254.6 \pm 1.91$ & $256.3 \pm 3.50$ & $256.6 \pm 1.44$ & $266.8 \pm 2.08$ & $266.0 \pm 1.27$ & 0.47 & 0.92 & $<0.01$ & 0.78 \\
\hline Period 3 & $270.4 \pm 1.99$ & $270.3 \pm 1.94$ & $271.3 \pm 2.63$ & $282.8 \pm 1.59$ & $283.6 \pm 1.78$ & 0.87 & 0.73 & $<0.01$ & 0.79 \\
\hline Period 4 & $281.7 \pm 3.31$ & $282.4 \pm 1.98$ & $283.7 \pm 1.47$ & $293.7 \pm 2.76$ & $296.7 \pm 1.93$ & 0.63 & 0.69 & $<0.01$ & 0.35 \\
\hline Period 5 & $289.4 \pm 4.22$ & $292.0 \pm 3.26$ & $293.6 \pm 2.27$ & $299.3 \pm 4.21$ & $304.0 \pm 1.43$ & 0.37 & 0.70 & $<0.01$ & 0.29 \\
\hline
\end{tabular}

${ }^{(1)} \mathrm{CON}$, mineral control; $\mathrm{N} 1800, \mathrm{CON}+1,800 \mathrm{mg}$ of narasin per kilogram of supplement; $\mathrm{N} 2750, \mathrm{CON}+2,750 \mathrm{mg}$ narasin per kilogram of supplement; PROT, protein mineral supplement (22\% crude protein); and PROT 360 , PROT $+360 \mathrm{mg}$ of narasin per kilogram of supplement. ${ }^{(2)}$ Orthogonal contrasts: I, CON vs N1800 and N2750; II, N1800 vs N2750; III, CON, N1800, and N2750 vs PROT and PROT 360; and IV, PROT vs PROT 360. 
explained by the high variability of pasture intake by the yearlings. In this line, Aubel et al. (2011) reported a low frequency of mineral supplement intake, since only $21 \%$ of the steers visited the feeder every day. In a recent study, Cappellozza et al. (2019) observed that $25.8 \%$ of the animals visited the feeder daily when fed the mineral supplement; however, when a proteinenergetic supplement was offered, the visit increased to $85.1 \%$. For the additives to express their full action potential, the intake must be frequent so that the input of the additive into the ruminal environment is constant. When ingested daily, narasin resulted in a better ruminal fermentation and improved the performance of lambs; however, when its consumption was spaced, with a greater interval between additive intake, the effects on the performance and fermentation parameters were impaired (Oliveira et al., 2018). These results are indicative that the use of mineral or protein supplements as a vehicle to supply ionophores for grazing cattle is still an inefficient method due to the irregular intake of these supplements (Cappellozza et al., 2019).

The levels of narasin did not affect any of the studied parameters, even though the amount of ionophores supplied by $\mathrm{N} 2750$ was higher than that by N1800, i.e., 167.8 vs $108.0 \mathrm{mg}$ per day during the whole experimental period. It is possible that there is a plateau in which the responses are similar throughout an inclusion range; however, there was no control of frequency intake, which has been considered more important for animal performance than dosage (Oliveira et al., 2018).

Although the inclusion of narasin into the protein supplement did not affect ADG (Table 5), yearlings fed this supplement had a greater ADG in the first and second periods, compared with those fed the mineral supplement, resulting in a greater BW at the end of every experimental period (Table 6). The highest ADG for the protein-supplemented animals in the first and second periods and the absence of effect in the other periods can be explained by the variation in the crude protein of the pasture, which was low in the first $(8.9 \%)$ and second $(8.4 \%)$ periods, but high in the third (13.8\%), fourth (11.6\%), and fifth (9.5\%) ones. Poppi \& McLennan (1995) reviewed several protein supplementation experiments and concluded that this type of supplementation induced an increase in ADG when low-quality forage was used, but had a weaker effect with high-quality forage. Protein supplementation decreased in relation to BW because the offered supplement was fixed in $500 \mathrm{~g}$ per animal per day as a fed basis, which did not take into account the increase in BW and, consequently, the energy requirement of the animals. In this case, an alternative would be considering the BW of the animals when supplementing their feed (Silva et al., 2010). The BW of the yearlings fed protein supplements was greater in all experimental periods, which was attributed to the increase in the ADG in the protein supplementation group in the first and second periods, showing that the use of protein shortens the livestock cycle, as reported in previous studies (Zanetti et al., 2000; Barbosa et al., 2007).

\section{Conclusions}

1. The positive effect of narasin on the average daily gain (ADG) of grazing yearlings is restricted to the first 28 days of supplementation, with no effect in a longer period of time.

2. The narasin levels added to the mineral supplement do not affect yearling performance, suggesting that the use of 1,800 mg per kilogram of mineral supplement is enough.

3. Narasin controls mineral supplement intake, without compromising ADG.

\section{Acknowledgments}

To Fundação de Estudos Agrários Luiz de Queiroz (Fealq), for support; and to the Hildegard Georgina Von Pritzelwitz experimental station of Fazenda Figueira, for allowing the use of their cattle and facilities during the study.

\section{References}

ALVARES, C.A.; STAPE, J.L.; SENTELHAS, P.C.; GONÇALVES, J.L. de M.; SPAROVEK, G. Köppen's climate classification map for Brazil. Meteorologische Zeitschrift, v.22, p.711-728, 2013. DOI: https://doi.org/10.1127/09412948/2013/0507.

ARKFELD, E.K.; CARR, S.N.; RINCKER, P.J.; GRUBER, S.L.; ALLEE, G.L.; DILGER, A.C.; BOLER, D.D. Effects of narasin (Skycis) on live performance and carcass traits of finishing pigs sold in a three-phase marketing system. Journal of Animal Science, v.93, p.5028-5035, 2015. DOI: https://doi.org/10.2527/ jas.2015-9314. 
AUBEL, N.A.; JAEGER, J.R.; DROUILLARD, J.S.; SCHLEGEL, M.D.; PACHECO, L.A.; LINDEN, D.R.; BOLTE, J.W.; HIGGINS, J.J.; OLSEN, K.C. Effects of mineral-supplement delivery system on frequency, duration, and timing of supplement use by beef cows grazing topographically rugged, native rangeland in the Kansas Flint Hills. Journal of Animal Science, v.89, p.36993706, 2011. DOI: https://doi.org/10.2527/jas.2010-3808.

AZZAZ, H.H.; MURAD, H.A.; MORSY, T.A. Utility of ionophores for ruminant animals: a review. Asian Journal of Animal Sciences, v.9, p.254-265, 2015. DOI: https://doi.org/10.3923/ajas.2015.254.265.

BAGLEY, C.P.; FEAZEL, J.I.; MORRISON, D.G.; LUCAS, D.M. Effects of salinomycin on ruminal characteristics and performance of grazing beef steers. Journal of Animal Science, v.66, p.792797, 1988. DOI: https://doi.org/10.2527/jas1988.663792x.

BARBOSA, F.A.; GRAÇA, D.S.; MAFFEI, W.E.; SILVA JÚNIOR, F.V.; SOUZA, G.M. Desempenho e consumo de matéria seca de bovinos sob suplementação protéico-energética, durante a época de transição água-seca. Arquivo Brasileiro de Medicina Veterinária e Zootecnia, v.59, p.160-167, 2007. DOI: https://doi.org/10.1590/S0102-09352007000100027.

BRANDÃO, R.K.C.; CARVALHO, G.G.P. de; SILVA, R.R.; DIAS, D.L.S.; MENDES, F.B.L.; LINS, T.O.J.D'.; ABREU FILHO, G.; SOUZA, S.O. de; BARROSO, D.S.; RUFINO, L.M. de A.; TOSTO, M.S.L. Comparison of protein and energy supplementation to mineral supplementation on feeding behavior of grazing cattle during the rainy to the dry season transition. SpringerPlus, v.5, art.933, 2016. DOI: https://doi.org/10.1186/ s40064-016-2603-9.

BRETSCHNEIDER, G.; ELIZALDE, J.C.; PÉREZ, F.A. The effect of feeding antibiotic growth promoters on the performance of beef cattle consuming forage-based diets: a review. Livestock Science, v.114, p.135-149, 2008. DOI: https://doi.org/10.1016/j. livsci.2007.12.017.

CAPPELLOZZA, B.I.; LASMAR, P.V.F.; REIS, F.T.; OLIVEIRA, L.; HOE, F.; BOEHLER, R.M.; LEIBOVICH, J.; STARKEY, R.; SIMAS, J.; COOKE, R.F. Effects of supplement type and narasin inclusion on supplement intake by Bos indicus beef bulls grazing a warm-season forage. Translational Animal Science, v.3, p.263273, 2019. DOI: https://doi.org/10.1093/tas/txy113.

FIESER, B.G.; HORN, G.W.; EDWARDS, J.T. Effects of energy, mineral supplementation, or both, in combination with monensin on performance of steers grazing winter wheat pasture. Journal of Animal Science, v.85, p.3470-3480, 2007. DOI: https://doi.org/10.2527/jas.2007-0127.

HORWITZ, W. (Ed.). Official methods of analysis of AOAC International. $17^{\text {th }}$ ed. Gaithesburg: Association of Official Analytical Chemists, 2000. 1219p.

JEFFERS, T.K.; TONKINSON, L.V.; CALLENDER, M.E.; SCHLEGEL, B.F.; REID, W.M. Anticoccidial efficacy of narasin in floor pen trials. Poultry Science, v.67, p.1050-1057, 1988. DOI: https://doi.org/10.3382/ps.0671050.

NEPOMUCENO, D.D.; PIRES, A.V.; FERRAZ JUNIOR, M.V.C.; BIEHL, M.V.; GONÇALVES, J.R.S.; MOREIRA, E.M.; DAY, M.L. Effect of pre-partum dam supplementation, creep-feeding and post-weaning feedlot on age at puberty in Nellore heifers. Livestock Science, v.195, p.58-62, 2017. DOI: https://doi.org/10.1016/j.livsci.2016.11.008.

OLIVEIRA, G.; POLIZEL, D.; FERRAZ JR., M.; MISZURA, A.; BERTOLONI, A.; BARROSO, J.; MARTINS, A.; SARDINA, L.; PIRES, A. Effects of narasin supplementation frequency on lambs performance. Journal of Animal Science, v.96, p.472-473, 2018. Suppl. 3. DOI: https://doi.org/10.1093/jas/sky404.1032.

POLIZEL, D.M.; BARBOSA, M.J.P.T.; CAPPELLOZZA, B.I.; LOPES, C.N.; FERRAZ JUNIOR, M.V.C.; GOBATO, L.G.M.; GOLCALVES, J.R.S.; PIRES, A.V. The addition of narasin into a mineral mixture improves performance of grazing Nellore steers. Journal of Animal Science, v.95, p.267, 2017. Suppl. 4. DOI: https://doi.org/10.2527/asasann.2017.545.

POLIZEL, D.M.; CAPPELLOZZA, B.I.; HOE, F.; LOPES, C.N.; BARROSO, J.P.; MISZURA, A.; OLIVEIRA, G.B.; GOBATO, L.; PIRES, A.V. Effects of narasin supplementation on dry matter intake and rumen fermentation characteristics of Bos indicus steers fed a high-forage diet. Translational Animal Science, v.4, p.118-128, 2020. DOI: https://doi.org/10.1093/tas/txz164.

POLIZEL, D.M.; FERRAZ JUNIOR, M.; MISZURA, A.; BARROSO, J.; MARTINS, A.; GONCALVES, J. ; LIMEDE, A.; CAPPEllozZA, B.; FERREIRA, E.; PIRES, A. Narasin improves performance of grazing Nellore yearling bulls. Journal of Animal Science, v.96, p.447, 2018. Suppl. 3. DOI: https://doi.org/10.1093/jas/sky404.976.

POPPI, D.P.; MCLENNAN, S.R. Protein and energy utilization by ruminants at pasture. Journal of Animal Science, v.73, p.278290, 1995. DOI: https://doi.org/10.2527/1995.731278x.

RUSSELL, J.B.; STROBEL, H.J. Effect of ionophores on ruminal fermentation. Applied Environmental Microbiology, v.55, p.16, 1989. DOI: https://doi.org/10.1128/AEM.55.1.1-6.1989.

SARTORI, E.D.; CANELLAS, L.C.; PEREIRA, G.R.; MOOJEN, F.G.; CARVALHO, H.R.; BARCELlOS, J.O.J. Performance of beef heifers supplemented with sodium lasalocid. Tropical Animal Health Production, v.49, p.273-279, 2017. DOI: https://doi.org/10.1007/s11250-016-1188-1.

SILVA, R.R.; PRADO, I.N. do; CARVALHO, G.G.P. de; SILVA, F.F. da; ALMEIDA, V.V.S. de; SANTANA JÚNIOR, H.A. de; PAIXÃO, M.L.; ABREU FILHO, G. Níveis de suplementação na terminação de novilhos Nelore em pastagens: aspectos econômicos. Revista Brasileira de Zootecnia, v.39, p.2091-2097, 2010. DOI: https://doi.org/10.1590/S1516-35982010000900030.

VAN SOEST, P.J.; ROBERTSON, J.B.; LEWIS, B.A. Methods for dietary fiber, neutral detergent fiber, and nonstarch polysaccharides in relation to animal nutrition. Journal of Dairy Science, v.74, p.3583-3597, 1991. DOI: https://doi.org/10.3168/jds. S0022-0302(91)78551-2.

ZANETTI, M.A.; RESENDE, J.M.L.; SCHALCH, F.; MIOTTO, C.M. Desempenho de novilhos consumindo suplemento mineral proteinado convencional ou com uréia. Revista Brasileira de Zootecnia, v.29, p.935-939, 2000. DOI: https://doi.org/10.1590/ S1516-35982000000300040. 